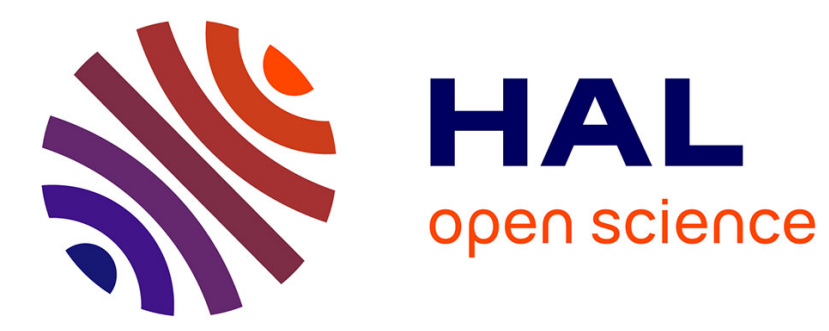

\title{
PDO project for Corsican pork as an innovation for the whole marketing chain
}

\author{
Adeline A. Derkimba, Etienne E. Verrier, François Casabianca
}

\section{To cite this version:}

Adeline A. Derkimba, Etienne E. Verrier, François Casabianca. PDO project for Corsican pork as an innovation for the whole marketing chain. 10. International Mediterranean Symposium, Nov 2008, Corte, France. pp.270-277. hal-01001155

\section{HAL Id: hal-01001155 \\ https://hal.science/hal-01001155}

Submitted on 3 Jun 2020

HAL is a multi-disciplinary open access archive for the deposit and dissemination of scientific research documents, whether they are published or not. The documents may come from teaching and research institutions in France or abroad, or from public or private research centers.
L'archive ouverte pluridisciplinaire HAL, est destinée au dépôt et à la diffusion de documents scientifiques de niveau recherche, publiés ou non, émanant des établissements d'enseignement et de recherche français ou étrangers, des laboratoires publics ou privés. 


\title{
PDO project for Corsican pork as an innovation for the whole marketing chain
}

\author{
Adeline Lambert-Derkimba ${ }^{1}$ et $^{2}$, Etienne Verrier $^{2}$, François Casabianca ${ }^{1}$ \\ ${ }^{1}$ INRA Laboratoire de Recherche sur le Développement de l'Elevage, Quartier Grossetti, 20250 Corte (France) \\ E-mail : derkimba@corte.inra.fr \\ E-mail : fca@corte.inra.fr \\ 2 INRA / AgroParisTech, UMR Génétique et Diversité animale, 16 rue Claude Bernard, 75005 Paris (France) \\ E-mail : verrier@agroparistech.fr
}

\begin{abstract}
A PDO project for Corsican pork began at the end of the 1990s. The objective of this paper is to show how this project could play a dynamic role by creating different types of innovations. We analysed the different steps in the construction of the project in the non-structured pork production sector in Corsica. We interviewed the main actors of the project and attended technical and political meetings organized by the PDO association.

The materials (discourse, grey literature) we analyzed enabled us to identify three innovations introduced by the project:

(i) In a project based on the valorisation of the "terroir" and of the territory, a change in the status of the local resources, in particular of the local breed;

(ii) In a project designed to fit European regulations, restructuring of the marketing chain with the creation of a new institution (the PDO association) and a new strategy for the sector;

(iii) In a project based on technical rules, producers have to respect the new production system including the exclusion of some producers who are unable to comply with the rules.

Even though the PDO project has not yet ended, we wondered if it could be a real driving force for the pork sector in Corsica.
\end{abstract}

Key words: Local breed, marketing chain, origin product, collective action, livestock system, pig, Corsica 